\title{
HUMAN RIGHTS: A CHANNEL FOR SALVATION?
}

\begin{abstract}
In the light of many severe social-economic and health problems many South Africans today experience a situation of helplessness and despair. In the face of these problems we ask whether there is a better solution than leaving the country and starting a new life elsewhere. If Christianity still has anything to say regarding these social-economic problems it must be the belief in salvation - salvation from a situation of helplessness and despair. The belief in salvation should appeal to and inspire people and therefore trigger change-oriented action. But does it happen in practice? To gain insight into this question we did empirical research among two groups of youths: a group of grade 11 students at some private (Catholic and Anglican) schools, and a group of grade 11 students at Afrikaans-medium public schools whom we investigated in a comprehensive survey research project, about their belief in God's salvation in the past, present and future, as well as in his salvation in both their personal relations and local and global communities. The question is whether this belief has an effect on their human rights culture, which theoretically can be positive or negative, or lead to no effect at all. The conclusion of this research is that their belief in divine salvation has a non-exclusive, differentiated positive effect. The effect is non-exclusive, because other religious factors like an open type of religious socialisation, ritual praxis and church participation, and more especially non-religious factors like gender, home language, political and cultural orientations also have an effect, sometimes even a stronger effect. The effect is differentiated, because only their belief in God's salvation in their personal life and their own communities has a positive effect on their human rights attitudes, whereas the other modes of God's salvific activity have a clearly ambivalent (positive/negative) effect or even no effect at all.
\end{abstract}

\section{Introduction}

People who find themselves in a situation of helplessness, frustration and disillusionment cannot always resist the temptation to retire to their corner and throw in the towel. That happens even when such feelings are short-lived, but even more so when they are a permanent state of mind because the underlying factors appear to be, or actually are, unalterable. This applies all the more when they affect not just one person but an entire group, community, a whole population. In that case the sense of helplessness and impotence may spread like an oil 
slick and there seems to be no agency or institution that can put a stop to it, let alone turn the situation around.

That is the situation in South Africa today; at any rate, that is how it is experienced by many groups. After the victory of democracy over the hegemony of the apartheid regime and the triumph of two successive free elections, the country appears to be plunged - at least in the experience of many communities - in an atmosphere of despair, even apathy (see Pieterse 2001, 97). Is there a better solution than leaving the country and starting a new life elsewhere? This is a realistic option only for a small minority of whites who can pride themselves on a good education (albeit at the expense of the whole population) and professional job experience. For other whites, either middle class or even underclass, the emigration option would be short-sighted if not socially cruel. And this applies even more to millions and millions of black people who are not just an underclass but a caste of downright untouchables. People to whom summer means rain drumming on the leaking corrugated iron roofs of their shacks and trickling in rivulets down their backs, who in winter have to protect their naked bodies with scanty garments against the biting cold, may well become cynical about the total lack of compassion and empathy concealed in the proffered prospects of distant lands and brilliant careers.

Will things ever come right for South Africa? Is the call for reconciliation reconciliation with the past, reconciliation between ethnic groups and within groups, reconciliation with oneself - not a total illusion? How can there be reconciliation when one is faced with an Aids epidemic which devours everyone who is young and promising around it, with no adequate medical help being offered or even available? How can there be reconciliation when one sees the degrading, even defiling poverty around one, the result of far too much for a small minority and far too little for the vast majority? (See Pieterse 2001a, 3070.) How can there be reconciliation if one is confronted every day with mindboggling crime statistics - theft, rape, murder - that fill people with a profound sense of insecurity? (Van der Ven \& Pieterse 1998.) How can there be reconciliation in the face of massive unemployment which makes young men and women feel they are wasting their lives and dissolving into a void? Is there still hope?

If Christianity still has anything to say, it must be the belief in salvation: salvation from a situation of helplessness and despair. But the message cannot and must not be an instant, facile solution, as though the truism "it will turn out all right in the end" will be realised through direct divine intervention, either now or hereafter. If Christianity still has anything to say, it is because the belief in salvation, as we apply the definition of religion by Geertz (1969), conveys an appealing perception of the world and human life (Christianity as a model of 
reality), and because it motivates people and triggers change-oriented action (Christianity as a model for reality). Finally, if Christianity still has anything to say, especially in the present situation in South Africa, it is because belief in salvation prompts people to claim and defend - even fight for - the human rights enshrined in the Bill of Rights in chapter 2 of the South African constitution. Why do we put the accent on the promotion of human rights as a task for Christianity? The answer is simply that human rights offer a legally enforceable solution to the manifold needs experienced by the majority of South Africans. Curbing the aids epidemic, combating poverty, containing criminality, reducing unemployment - all these require the implementation of the most fundamental human rights, such as the right to life, health, sanitation, food, housing, education, work. In short, Christianity must help to invigorate an inspiring human rights culture, otherwise it will lose all relevance.

Of course, this plea for a vigorous, inspiring human rights culture as a task for Christianity is nothing new. It has been presented repeatedly over the past decade, both in scientific forums and in ecclesiastic and pastoral circles. And it was addressed mainly to the youth; they, after all, are the future bearers of society and culture (cf Khumalo 1999; Ndlovu 1999).

Hence it is important to discover whether there has been any change, either positive or negative, in recent years and, more specifically, whether young people's faith in salvation has contributed positively or negatively to an inspiring human rights culture than in the past.

To gain insight into this theme we focussed on two groups of youths: a group of grade 11 students at some private (Catholic and Anglican) schools, and a group of grade 11 students at Afrikaans-medium public schools. The reason for this choice was that private schools have had a multicultural student population all along and have always pursued a multicultural policy, whereas Afrikaans-medium public schools were characterised by the monoculture of the white minority. For the private school students we have questionnaire data from 1995 (538 students) and 2000 (495 students); for the public school students we have similar data from 1996 (283 students) and 2001 (607 students). ${ }^{1}$

In analysing these data we looked for answers to the following questions:

1(a) What similarities and dissimilarities are there between the belief in salvation among private school students in 1995 and 2000 and among public school students in 1996 and 2001 ?

1(b) How do students evaluate this belief?

2(a) What similarities and dissimilarities are there in regard to a human rights culture between private school students in 1995 and 2000 and between public school students in 1996 and 2001 ? 
2(b) How do students evaluate the human rights culture?

3(a) How did belief in salvation contribute to a human rights culture among private school students in 1995 and 2000 and among public school students in 1996 and 2001?

3(b) What other important factors, apart from the belief in salvation, influenced the human rights culture?

Against this background the article is divided into three parts. The first looks into students' belief in salvation with a view to answering questions 1(a) and 1(b). The second explores the human rights culture among students so as to answer questions 2(a) and 2(b). And part three examines the positive or negative contribution, or the absence of any contribution, of the belief in salvation to an inspiring human rights culture with a view to answering questions 3(a) and 3(b).

\section{Salvation}

In empirical research one needs to have an appropriate theoretical framework within which to take all sorts of decisions on scientific, legitimate grounds. If not one may end up doing little more than a kind of market research, in which the relation with scientific theorising is either disregarded or even deliberately pushed aside. Hence in determining what notions of salvation the two groups of students have and whether they have changed over the past few years, we have to do four things. First we need to draw up an adequate soteriological framework (1.1) in order to develop a semiotics of soteriological codes that is relevant to our research (1.2). From this we have to infer the soteriological codes which we assume, on theoretical grounds, to function among our students (1.3). Finally we must determine whether this assumption holds water by describing the empirical codes which we have collected by means of our questionnaire research (1.4).

\subsection{A Soteriological Framework}

To a faithful churchgoer the question at the top of this article may seem peculiar, strange, even alienating; it may even incur suspicions of heresy and blasphemy. Is working for human rights not a human activity, something accomplished by human hands, whereas salvation primarily calls to mind an activity, even the activity of God? Moreover, is the aim and perspective of salvation not the realisation of God's kingdom in this world, to which people may know they are called and to which they may in gratitude feel bound to contribute? Human rights, by contrast, are not a human duty but put the accent on rights; something that people submit to the law-givers and the courts when they feel that their 
rights are not respected, or not sufficiently respected. By putting the accent on the relation between salvation and human rights, God in a sense takes the backseat, and with him his kingdom, while the emphasis on human rights replaces gratitude and obligation with a sense of self-regard and entitlement.

The objection raised here pictures human beings' relation to God as one of competition, as though what God does is not done by people; as if whatever God does, people do less; as if what God gives people simply receive. Is the counterpart of God's transcendence in fact human immanence, that of God's greatness human puniness, that of God's light human darkness? Or is the counterpart of God's transcendence his immanence, that of his greatness his smallness, that of his light his darkness? And do human beings not also know the dialectics of transcendence and immanence, greatness and smallness, light and darkness?

Anyone who really probes these - rhetorical - questions will realise that the relation between God and human beings is not competitive, not even reciprocal, but mutual. God and human beings are not in competition, as if what God does is subtracted from humans or, conversely, what people do is subtracted from God. God does not replace human activity, he does not eliminate it - the mere thought detracts from his greatness-in-smallness. ${ }^{2}$ Neither do God and human beings alternate, as happens in reciprocal relationships, as though the two are alternately active and passive, alternately giver and taker, creditor and debtor. The relationship between God and humans is a love relationship of genuine mutuality, in which, as in authentically human love, both partner are simultaneously active and passive, express their greatness and smallness, give and take. In mutual self-giving they receive both the other and themselves, and in mutual receiving they give themselves to the other and to themselves (Ricoeur 1994).

However persuasive and even eloquent this description of the intertwinement of human and divine activity may be, the almost mystical ecstasy it reflects requires to be examined at a conceptual level: how should we interpret this active conjunction of God and human beings? To answer this question one can start from both sides: either proceed from God's acts and use these to explain human actions, or conversely, proceed from human activities and use these to clarify God's actions. Here we opt for the second alternative.

Hence our premise is that salvation may be conceived of primarily as a human activity. In other words, human beings themselves accomplish their own salvation through carefully considered planning, clear-minded decision making, active intervention and evaluation based on feedback. 
This statement, which we have deliberately formulated as boldly as possible, calls for some qualifications. The first is that the series comprising planning, decision making, intervention and evaluation does not assume that the human act of salvation is entirely conscious. A lot of the things we do in life, nearly all of them in fact, are done - thank God - unconsciously by way of a large range of routines, habits, rituals and institutional procedures. But what distinguishes human behaviour from that of animals - if we ignore the borderline area of primates - is that people can reconstrue their behaviour afterwards in an intentional sense as $m y$ actions directed to (an interlinked series of) $m y$ goals.

The second qualification is that these actions are never those of a monad, as if I alone independently determine my life in total isolation from everybody and everything. My actions are always actions-in-relation-to-others, relations which also assume varying forms, from mutual cooperation to competition, from selfless giving to exclusion of others. It also means that my actions are marked, not just by activity but also by passivity: from receiving to toleration of others, from being influenced to being wholly determined by others.

The third qualification is that the actions which - in a reconstructive sense - are interpreted as salvation are not momentary actions aimed purely at the here and now but actions which, whilst taking place in the here and now, are imbedded in experience gained from actions performed in the past as well as in expectations reaching out to the future. Actions only occur in the present - where else? - but they are based on past experience of action and fall within the horizon of future expectations. ${ }^{3}$ In addition past and future can entail the more recent past and the near future, or the more distant past and future. At a higher level of abstraction actions can touch on the entire lifespan, to the extent that present actions may incorporate the horizons of both birth and mortality. Indeed, they may even be determined by stories of the mythological beginnings of all action in the primordial past and of the mystical consummation of all action in the eschatological future, a theme to which we return in due course.

The fourth and final qualification is that human salvific activities are not to be founded, so to speak, in nature, as though we can observe and identify them with the naked eye, without any reflection. Just as human action is an interpretive category - we interpret behaviour (afterwards) as action - so is salvation. Without reflection there is no action, without reflection there is no salvation. We interpret behaviour as action, and only then - here we are analysing conceptually what is experienced holistically - do we interpret this action, or some actions, as salvation.

The question is: where does God fit into this picture, where is his salvific action? Has God been cut out of the picture completely, has the perspective on his 
salvific action been lost? That only happens if we proceed, consciously or unconsciously, from a dualism between God and humans, something we have explicitly rejected. But the question of the relation between the human action of salvation and the divine action of salvation is no less pressing.

Do we denigrate God's salvific action when we refer to it as a second-order interpretive category? First we interpret behaviour as human salvific action and then - again, we are analysing conceptually what is experienced, at any rate by believers, holistically - we interpret it as divine salvific action. There is no experience of God's salvation that is not structurally characterised and determined by reflection (Andresen 2001). It applies equally to the emphasis that members of revivalist movements and charismatic congregations put on the immediate presence of God, Jesus and the Spirit in the hearts of believers. Here it is a matter of a experience of that presence, which as an experience, is totally, we repeat, a matter of interpretation, even if only by the interpretive context of the ritual service, including its music, songs, prayers, readings, sermons, dialogues and blessings. To put it more generally: the revelation of God's salvation occurs only in human experience and interpretation of what salvific actions human beings themselves perform in the perspective of divine transcendence. The contrast that is made between revelation and experience is totally misplaced, since God's revelation enacts in human psychic structures. Outside these structures human beings are unable to experience anything, not even divine salvation. That was taught already in high scholasticism, notably by Thomas Aquinas. What, then, is the relation between divine salvation and human salvation? What is its distinctive quality? Is there not some duplication - is divine salvation more than just the replication of human salvation at a more abstract level, a higher aesthetic plan, in a more satisfying ritual mode?

The distinctive nature of divine salvation can be determined by means of two sets of paired concepts: gift and task, inspiration and orientation. To believers the human salvation they accomplish signifies a gift which entails a calling, a way to travel, a destination that shapes their identity. It is a gift that also entails a task. When believers actively dedicate themselves to the cause of salvation, they know that this task has been given to them by God: God gives them the business of salvation to accomplish. The structural link between gift and task forms the basis of the gratitude with which believers perform their task, and in it they find the strength and courage to continue and persevere in the face of setbacks.

In addition to the paired concepts of gift and task, there is another pair: inspiration and orientation. God's faithfulness in the primordial past, as expressed in the stories of creation, the patriarchs, the exodus, the sojourn in the wilderness, the entry into the promised land, these can inspire believers and fill them with 
enthusiasm. Thus the gift becomes inspiring, exhilarating. God's faithfulness in the eschatological future as expressed in tales of the wholeness of the individual beyond death, the harmony among people and between people and animals, shalom, the new Jerusalem, the new creation, the new heaven and the new earth, can give believers a hold on the direction they should follow, the course they should pursue, the perspective they should cling to. Thus the task is not blind but orienting.

What conclusion can we draw from this reflection? The most important is that human salvation and divine salvation are not complementary, let alone in competition. God and humans do not compete, but neither do they complement each other, as though the whole must add up to $100 \%$ : each party is actively engaged in the process of salvation to arrive at the total of $100 \%$. The way it happens is best conceptualised as transcendence-through-immanence, implying that God's salvific action occurs via human salvific action without being assimilated to it. This leaves the dual structure of gift/task and inspiration/orientation intact.

\subsection{A Soteriological Semotics}

Against the background outlined in the previous section we can develop a soteriological structure for our study of our students' notions of salvation. To this end we apply a semiotic procedure which enables us to distinguish between the deep level of soteriological codes and the surface level of soteriological signs. The signs are the actual images and metaphors that our students used, so we assumed, in order to articulate the notion of salvation. The codes underlie these, the signs emerge from them and are directed by them. But apart from the distinction between deep level and surface level that characterises the difference between signs and codes, we need to take note of another fact: that of the plurality of signs and codes. A code can give rise to a, theoretically, infinite number of signs: that is code/sign plurality. Thus the code "God's salvation here and now" can give rise to divergent signs/images such as "the task we have to work on the kingdom now" or "the task once given to us by God to look after the earth". In addition the same code can, in different contexts, give rise to various meanings for one and the same sign: that is context/code/sign plurality. Thus the code "God's salvation in the past", when it is used in different contexts (e.g. a rural or an urban one), can result in diverse meanings of a sign, such as "the paradise on earth which God created for us in the beginning".

The distinctive feature of codes is that they are binary or paired opposites, based on polarised contrasts rather than on contradictions. One cannot say, for example, that God's salvation both occurs and does not occur here and now, that it is both a gift and not a gift (contradiction); one can say that it occurs both in the present and in the future, that is it is both a gift and a task (contrast). In effect 
we develop a soteriological semiotics of binary codes relating to the belief in divine salvation, conceived of as human salvation in a perspective of transcendence. From each code we infer certain items, on the assumption that it functions as a sign that represents divine salvation, and we do so according to the way in which the code refers to God's salvation. The resulting list of items constitutes the instrument with which we seek to trace our students' soteriological notions.

The binary oppositions from which we developed the semiotic structure are the following:

(1) transcendent versus immanent, referring to God's salvific involvement with people and the world in a manner that totally transcends them, or in a manner that locates God's salvific activities entirely in human actions;

(2) present versus past, referring to God's salvific activities here and now or his activities in the primordial past, prior to any human action of whatever kind;

(3) present versus future, again referring to God's salvific activities in the present, as opposed to God's consummating actions in the eschatological future, beyond all human actions of whatever kind;

(4) intrapersonal versus interpersonal, implying that the human salvific activities in which God's actions are embodied are enacted within the individual, or in the person's relations with other people; and finally

(5) local versus global, indicating that the human salvific activities in which God's salvation is realised are enacted at either a local or a global level.

We proceed on the assumption that there are no major soteriological structures relevant to our research that cannot be traced to these five binary oppositions or combinations of them. We shall now examine these binary codes more closely.

Transcendent versus immanent. Both concepts occur in the Christian tradition. The one emphasises the redemptive God who, prior to and independently of human action, brought salvation which people, through their innocent and culpable fallibility, cannot accomplish for themselves, even though they are themselves responsible for the plight in which they find themselves and the harm that they have done. The other is the belief that God is a symbolic metaphor referring to the novel, unexpected, startling way in which people construe their dire situation and, through this reconstruction, transform it. These are two extremes: in the first case human action contributes nothing but merely constitutes the material for God's action, a view encountered in orthodox and neoorthodox circles. In the second case divine action contributes nothing and the word "God" can be replaced by any fictional, literary, poetic and hence social or individual therapeutic strategy, a view encountered among proponents of a 
liberal kind of cultural Christianity. Both notions derive from a philosophical structure that conceives of a dualism between God and human beings: the first notion is the positive expression of it, the second the negative reaction to it.

From what we have said it should be clear that in this article we have consciously and explicitly opted for maintaining a dialectic tension between transcendence and immanence. We said that God gave humans a salvific task of their own; he does not exclude them, does not ignore human salvific actions but in fact calls people to perform them and is personally present in these activities. How else are we to understand the discourse attributed to Jesus in Matthew 25, that jewel of biblical imagination? In the salvation that you brought to the afflicted, Jesus said, I am personally present. Jesus identifies himself with the hungry who are given food, with the thirsty who are given drink, with the naked who are clothed, with the prisoner and the sick who are comforted and heartened by a visit; at the same time he identifies these salvific acts as blessed by the Father. The blessing is more than a rhetorical ritual to conclude a church service; it refers to God's presence in human actions, through which humans participate in God's salvific work (cf Halkes 1989, 95-102). But there is more: in the discourse attributed to Jesus we also read that we do not know as yet who has performed salvific actions and who has not; the book of life will only be opened and read at the end of time. Should this not lead us to conclude that it does not behove us - that it is in fact arrogant - to work out now who has and who has not realised God's salvation in their actions? We have pointed out already that salvific actions are not momentary acts aimed only at the here and now, because they should also allow for action experienced in the past and action anticipated in the future. Hence it is premature to want to separate the sheep from the goats in the here and now, even in regard to the past, because that too changes constantly - in a reconstructive sense - on the basis of each new here and now. However, to amplify and deepen this action theory consideration, the story of Matthew 25 should also be read as a more specific, here a religious motivation to refrain from any soteriological tests whatever in the here and now. One can see it as a spiritual summons to the virtue of humility - "let us not pride ourselves on belonging among the sheep, not the goats"- but a much more profound insight is that we really do not know where the dividing line between sheep and goats lies. We may have our surmises, expectations, our hopes, but no certain knowledge. God's kingdom is near, but we don't know where! (Van der Ven 1998, 365-378.)

Present versus past. In this case, too, we were able to determine that both notions occur in the Christian tradition. The first notion puts the accent exclusively on the present in which God's salvific activities are accomplished. This actualist view explicitly or implicitly rejects any kind of soteriological retrospection, as if God was confined to a kind of "golden age" in the past; but it also rejects any 
soteriological prospection, as if God is entirely future, like some distant utopia, as if he is the future. Instead it advocates introspection aimed at recognising and acknowledging God's salvific presence in the depths of human existence and/or the deep level of society (Moltmann 1964). In the second view, by contrast, the emphasis is exclusively on God's salvific acts in the past, especially the primordial past which is not just the first phase of history but its beginning, thus constituting all history as we know it (cf Barth 1960; 1964; McGrath 1994). This concerns the original stories of creation and of every new beginning which, in the fictional literature of the Bible, invariably refer back to the stories of creation, at the same time reinterpreting them inter-significatively in each instance, as in the stories of the covenant, the exodus, the entry into the promised land, et cetera (Ricoeur 1998). It was then, in the beginning, at each new beginning, that God established salvation for humans and made them share in it for ever, so all one has to do is commemorate the narrative and celebrate the multiple origin ritually, thus internalising and constantly re-internalising it.

It will come as no surprise that, in terms of our argument so far, we should prefer to keep the dialectic tension between past and present intact. On the one hand actualism poses the danger that concern with the foundational stories of the primordial past will lessen and we will be blinded by the tasks facing us in the present, without pausing in gratitude to consider the treasure entrusted to us long ago as a tradition to be handed down from one generation to the next. On the other hand what we might call "primordialism" poses the danger of a flight into the past, in which the romantic notion of salvation established long ago may prove illusory because its ever new significance for the present and the future is not deciphered. Does every age not represent a new beginning which, in terms of the great epics, demands fresh interpretation and reference each time?

Present versus future. The notion of God's salvific action in the present versus his salvific actions in the future is the mirror image of the previous binary opposition. Over against soteriological actualism, which puts the accent wholly on the present, is the eschatological, even apocalyptic, hope which puts the focus exclusively on the definite coming of divine salvation as a radically new creation: a miraculous gift that only God can bring about. Only God and God alone, in his grace, can create and present us with his kingdom in which believers can share (Berkhof 1973, 544; König 1999, 81-88). A typical Reformed view is the following: "The Christian conception of heaven is essentially that of the eschatological realisation of the presence and power of God, and the final elimination of sin. The most helpful way to visualise it is to regard it as the consummation of the Christian doctrine of salvation, in which the presence, penalty and power of sin have all been finally eliminated, and God's total presence in individuals and in the community of faith has been achieved"'(McGrath 
1994, 476). A milder version is the notion that God's salvation in the future should be seen as an "apocalyptic interruption" which will not destroy all continuity with what people had done up to that "moment", but in which discontinuity will still predominate (Metz 1981).

Against the background of the views expressed above, we cannot but prefer to keep the dialectic wholeness of past, present and future intact, or even better, the dialectic wholeness of present and past and of present and future, through which past and future are interlinked (cf Heidegger 1979; Ricoeur 1984). The same applies to God's salvific acts. Salvation is an exceptionally complex idea, embracing not simply a future event, but also something which has happened in the past. But the relation between present and future is no less important than that between past and future: after all, believers know that they are called to work for the coming of the God's kingdom as God's co-workers, reciprocally, in the power of his Spirit (Pieterse 1993, 137; Van Ruler 1969). Temporally the eschaton does not await us only in the future but is already in the present: it is in the here-and-now of the world (Moltmann 1969, 5-25). In the salvific diaconate of people in all spheres of society the kingdom of God is accomplished in an anticipatory but effective manner (cf Heitink 1999).

Intrapersonal versus interpersonal. Here the question is whether God's salvific activities occur in and via activities that people perform in their inner selves or in the social relations of love and justice that they maintain with others. In the first case the accent is on activities like individual introspection, contemplation, reflection, meditation and prayer. It means that people establish contact with feelings lurking in the depths of their existence in order to be freed from unconscious, negative feelings of frustration and alienation, that they open themselves to the positive feelings hidden beneath the negative burden on their inner selves, and thus achieve peace and reconciliation with themselves. This healing inward journey, characterised by the active passivity and passive activity of receptiveness, is also the way in which God salvifically reveals himself to people in the depths of their existence. It is the way in which humans and God encounter one another, both in meditation - which implies thought that both originates in and leads to God - and in prayers of love and thanksgiving. In this human selfredemption God's redemptive acts take place, without being assimilated to it.

In the second case God's salvific activities are located in the mutual support that people give each other, in which they act as peacemakers to each other. The main forms that this takes are love and justice. Love aims at optimal realisation of the other person's human talents, so that they may develop to the highest possible joy and happiness (i.e. flourishing). Justice aims at proportionally equal distribution of liabilities and desires, duties and rights, responsibilities and privileges. The two presuppose and need each other. Love is needed so that 
justice does not degenerate into a crude, arithmetical justice of exchange based on the principle of do ut des. Justice is necessary so that love will not end up in the pitfalls of hidden egocentrism (love only for oneself), "philiacentrism" (love only for significant others) or sociocentrism (love only for one's community) instead of being directed, not only to the other (alter) but especially to strangers (aliens) from outside our own community who, as human beings with their own dignity, are no less entitled to recognition and respect of their human rights as members of our own community. The golden rule from the Bible, both the Jewish Bible and the New Testament, "Treat others as you would be treated", which also occurs in the scriptures of other religions, can easily be interpreted in a "philiacentric" and sociocentric way, thus violating the stranger's right to recognition (Schillebeeckx 1977). A more abstract interpretation of this in Kant's categorical imperative ("treat humanity in one's own person and in the person of others as an end in itself and not simply as a means"; see Ricoeur 1994, 219) broadens the focus to include everyone who shares in our very existence: humanity (Ricoeur 1994, 262, 266). Ricoeur puts it pertinently: "Treating others simply as means is already starting to do violence to them" (Ricoeur 1994, 266).

Once again an option for either intrapersonal or interpersonal salvation seems an unnecessary dilemma. To be sure, overemphasis of intrapersonal salvation can lead to monadic solipsism, but interpersonal salvation may just as easily lead to a purely extroverted, bustling diaconate. On the one hand the rich mystical tradition of intrapersonal salvation refers to the inner person as a launching pad for an extroverted salvific orientation, as is evident in the dialectic between the mystical metaphors for the inner self - cell (cella), house (casa) and city (citta), in the work of Catherine of Siena (Fresen 1995, 113-227). On the other hand the salvific, pacifying work of love and justice requires sustained spiritual nourishment from within in order not to run dry and to avoid aridity, which would jeopardise the inspiration and orientation of the salvific human activities mentioned above.

Local versus global. Nowadays people are more convinced than ever that concern for global peace and harmony goes hand in hand with concern for local peace and harmony, and vice versa, since each presupposes and influences the other. The reason is that globalisation is characterised by an extension of space (distance no longer matters) and of time (working time has stretched to 24 hours of the day), and at the same time by a compression of space (different networks are linked to each other on the spot) and time (its passage is ever more rapid). What happens or fails to happen in place $A$ has direct repercussions for developments in places B, C and D elsewhere in the world. This global interdependence binds local groups and communities more closely together than ever before. Thus Pakistani opposition to the American war against political Islamic 
fundamentalism in Afghanistan in 2001 evoked similar protest among certain groups in rural areas in South Africa and the Netherlands, while the same protests became a leading theme in front page news in the Herald Tribune. The same applies to people's salvific actions which embody divine salvation in place A (or the lack of such action, resulting in an absence of divine salvation), and their repercussions in developments in places B, C and D elsewhere in the world. In more abstract terms, salvific actions here and now (or the lack of them) have implications for the whole of humankind, in one way or another. Here Kant's categoric imperative applies even more forcefully: "treat humanity in one's own person and in the person of others as an end in itself and not simply as a means", since in the context of growing global interdependence "the person of others" and "humanity" increasingly coincide. In the African context, the humanity of the other is expressed in the concept of ubuntu or true humaneness, implying the value of universal brotherhood in which sharing and treating other people as humans are concretised (Prinsloo 1998, 41), as well as the values of empathy, congruence and open communication. As a result nobody becomes an object of violence and hence a victim (Makhudu 1993).

\subsection{Theoretical Codes}

Against the background of these binary oppositions, including combinations of them, we developed six theoretical codes referring to God's salvific action, spread over two groups: codes referring to the character and codes referring to the place of God's salvific action in and through human salvific actions. As may be seen in table 1, we divided the three codes relating to the character of divine salvation into two: an immanent-transcendental code and two transcendent codes. The immanent-transcendent code refers to God's presence in salvific human action here and now, whereas the transcendent codes refer to divine salvation in the primordial past and in the eschatological future.

\section{TABLE 1: Theoretical codes}

\section{Character of God's salvific action}

1. immanent transcendence in the present $\quad(9,11,17,19)$

2. transcendence in the primordial past

3. transcendence in the eschatological future $(6,13,18)$

Place of God's salvific action
4. intrapersonal
5. interpersonal/local
6. global

$(7,8,20)$ 
The remaining codes, referring to the place of God's salvific action, relate to intrapersonal, interpersonal/local, and global human salvation in which divine salvation manifests itself in three ways. We assume that these six codes are present in the students' consciousness, which is to be tested empirically. We call these codes theoretical because they are formulated and compiled on theoretical grounds. ${ }^{4}$ They are operationalised in a total of 20 items, as indicated in brackets after each code.

\subsection{Empirical Codes}

To analyse students' scores on the 20 items we made use of the statistical method of factor analysis. This enables one to determine the interrelationship between items and thus to divide them into empirical groups. Factor analysis assumes that the interrelationship between items is attributable to one or more underlying phenomena called factors. With due caution one might say that what is called a factor in factor analysis, which underlies the items, parallels what is called a code in the semiotic procedure, which underlies the signs. In other words, the theoretical semiotic structure that we developed earlier is comparable to the empirical semiotic structure arrived at via factor analysis.

TABLE 2: Empirical codes

Character of God's salvific action

1. immanent transcendence in the present

2. transcendence in the primordial past

3. transcendence in the eschatological future

private/public private/public Total $\begin{array}{llll}1995 & 1996 & 2000 & 2001\end{array}$

$\begin{array}{lllll}3.7 & 4.1 & 3.6 & 4.0 & 3.9 \\ 3.6 & 3.8 & 3.5 & 4.0 & 3.7 \\ 3.9 & 4.4 & 4.0 & 4.3 & 4.2\end{array}$

Place of God's salvific action

4. personal/local

5. global

$\begin{array}{lllll}4.0 & 3.8 & 3.9 & 3.9 & 3.9\end{array}$

We conducted two separate factor analyses on private school students' scores in the 1995 study: one on the scores relating to the character of God's salvific activity and the other on those relating to the place of God's salvific activity. For the sake of the commensurability of the 1995 data with those of 1996, 2000 and 2001 we took the factor structure of the 1995 study as our basis for scale construction for all four populations and, in the studies of the other three years, confined ourselves to determining the statistical reliability of the scales we had constructed. As in the factor analyses conducted in other thematic domains in the Religion and Human Rights Project, smaller and bigger differences between theoretical and empirical codes kept emerging (for the difference between theoretical and empirical codes, see e.g. Van der Ven, Dreyer \& Pieterse 2001, 
181-186). From a comparison between table 1 and table 2 it emerges that the theoretical and empirical soteriological codes relating to the character of God's salvation appear to overlap, but those relating to the place of God's salvation do not. The intrapersonal and interpersonal/local codes turned out to constitute only one factor, not two, so we labelled it "personal/local".

Table 2 presents the empirical codes with the average scores for the years 1995 and 2000 (private schools) and 1996 and 2001 (public schools), the last column containing the total average scores of the four year groups together.

In the introduction we asked the question: what are the similarities and differences between the belief in salvation of private school students in 1995 and 2000 and of public school students in 1996 and 2001 (question 1 (a)? In order to be able to answer this question we first compare the 1995 scores of private school students with the 1996 scores of public school students, and then the 2000 scores of private school students with the 2001 scores of public school students. Next we compare the 1995 scores of private school students with those for 2000, and then the 1996 and 2001 scores of public school students. In these comparisons we take a difference score of 0.5 or more as our criterion of relevance on the five-point scale on which the scores are based.

The answer to question 1(a) is as follows. The striking feature is that there is only one relevant difference, according to the criterion defined above, in the comparison between 1995 and 1996, and that is as regards God's salvific presence in the eschatological future: whereas the private schools students agree with this (3.9), those in Afrikaans-medium public schools agree strongly (4.4). The comparison between 2000 and 2001 likewise yielded only one relevant difference, namely in regard to God's salvific presence in the primordial past: here the public school students scored noticeably higher (4.0) than those in private schools (3.5). Even though neither the comparison of 1995 and 2000, nor that of 1996 and 2001, produced any relevant difference, the two differences that did emerge point to a stronger orientation to transcendence among public school students than among students in private schools.

We now turn to the answer to question 1(b): how do students evaluate the belief in salvation? $?^{5}$ First, the scores indicate that students clearly agree with every one of the five images of salvation $(\geq 3.40)$. This means that they agree not just with one particular image of salvation but with a plurality of salvation images. This finding cuts the ground from under the feet of those who, on the basis of their own belief and/or obedience to the (supposed) word of God in the Bible and tradition, try to steep their audience in that one image of salvation in terms of which God is said to have realised his relationship with humankind and the world, be it God's immanent transcendent salvation in the present (code 1), 
God's transcendent salvation in the primordial past (code 2), God's transcendent salvation in the eschatological future (code 3), God's salvation in the intrapersonal and interpersonal/local domain (code 4), or God's salvation in a global sense (code 5). To our students salvation - or at any rate its image manifests itself only in the plural.

We want to highlight two other data. The first is that God's immanent-transcendent salvation in the present scores consistently higher than his primordial salvation in the past, but consistently lower than his eschatological salvation in the future. The pattern of soteriological preference of students in both types of schools runs from past to present to future, also evidenced by the aggregate average scores of the year groups in the final column $(3.7,3.9,4.2)$. While this may strike the reader as an aesthetically ascending series, it contradicts the expectations implicit in the views we have outlined. These proceed from a twofold series, present/past and present/future, the highest rating being assigned to God's salvation in the present, with both past and future salvation regarded as implicit in, and hence derived from, present salvation. The students display a different pattern, in which the future is given the highest rating - although one should not attach too much value to it, since the differences are not relevant. Yet the question remains: does the preference for God's salvation in the future arise from fairly great, not easily resolved frustration and alienation in presentday society and culture?

The second point we want to make is the preference for the personal and the local rather than the global as the place of God's salvation. Again we cannot attach too much importance to it, since the differences are not relevant. Nonetheless it is a striking, if understandable, finding that the students are oriented primarily to salvation in their immediate environment, while in this sphere global processes take second place.

In sum, our students appear to be very religious as far as their belief in God's salvation is concerned. They agree with all aspects of this belief, especially God's transcendent salvation in the eschatological future (4.2), which means that they really hope for a good future, and God's personal salvation in their own life and their own local communities (4.2), but also God's immanent transcendent salvation in the present, which mean that they believe in salvation now (3.9) and God's salvation in the global world (3.9), which refers to other communities, farther away, albeit a little bit less so. Their belief in God's transcendent salvation in the primordial past is less strong, nevertheless they agree with it also (3.7).

However positive this overall picture may be from the perspective of the Christian faith, the most important question is whether and to what extent this strong 
belief in God's salvation really influences their human rights culture, because their high degree of Christian belief does not automatically mean that this belief also prompts their attitudes towards human rights. The causal relation between their belief in divine salvation and their human rights orientations might be positive or negative, or there might be no effect at all, which implies a so-called zero-effect. To make this more concrete: will the two modes of salvation in which the students believe most strongly, i.e. God's salvation in the eschatological future (4.2) and God's salvation in the student's personal and community life (4.2) have the strongest effect on their human rights culture? In the following sections we will discover what the answer to this question is.

\section{Towards a Human Rights Culture}

Having completed our study of our students' belief in salvation, we now turn to the next two questions posed in the introduction. These pertain to these students as vehicles of a human rights culture. Are there any differences and similarities in this regard between private school students and those at Afrikaans-medium public schools in 1995, 1996, 2000 and 2001? And how do they assess a human rights culture?

The problem is on which human rights we should focus so as to determine the students' human rights culture. Since this topic was dealt with at length elsewhere, we merely summarise the conclusions of this earlier research (Van der Ven, Dreyer \& Pieterse 2000a; 2000b).

According to a relatively longstanding tradition human rights may be divided into three generations: blue rights, red rights and people's rights. Blue rights have a fairly liberal background, as they stem from the Anglo-Saxon world; red rights have a social-democratic character; and people's rights emerged particularly from the concerns of developing countries. Following Michael Haas who, after the example of Charles Humana's World human rights guide, empirically researched the one-dimensional or multidimensional character of human rights, we distinguish between three kinds of human rights in the first generation of blue rights: civil, political and judicial rights. Again following Haas, we treat the second generation, red rights, as a single group entitled socioeconomic rights. Finally we add environmental rights as an example of the third generation, people's rights. Thus we have a multidimensional human rights culture: a civil rights culture, a political rights culture, a judicial rights culture, a socioeconomic rights culture, and an environmental rights culture.

As is evident in table 3 , we differentiate six rights in the civil rights culture (freedom of speech, freedom of the press, freedom of assembly, right to priva- 
cy, freedom of lifestyle, freedom of religion); three in the political rights culture (rejection of political oppression, political action, political interest); and four in the environmental rights culture (environmental action, appreciation, sacrifice and concern). Together with the judicial rights culture and the socioeconomic rights culture, this amounts to five human rights culture categories, giving us a total of 15 rights.

Having taken this decision, we asked our students to respond to various lists of items, which should be seen as an operationalisation of the five human rights culture categories that we identified. ${ }^{6}$ We conducted a number of statistical analyses on the private school students' responses in 1995 in order to construct adequate scales to measure their involvement in the various dimensions of a human rights culture.

For the sake of the commensurability of the 1995 data with those from 1996, 2000 and 2001 we again took the scales constructed for the 1995 study as our premise, and for the other three years we confined ourselves to determining the statistical reliability of the relevant scales.

\begin{tabular}{llllll}
\hline TABLE 3: Human rights culture & & & & & \\
& $\begin{array}{l}\text { private } \\
\text { public }\end{array}$ & $\begin{array}{l}\text { private } \\
\text { public }\end{array}$ & total \\
Civil rights culture & 1995 & 1996 & 2000 & 2001 & \\
freedom of speech & & & & & \\
freedom of the press & 3.3 & 2.9 & 3.7 & 2.9 & 3.2 \\
freedom of assembly & 2.7 & 2.5 & 2.9 & 2.3 & 2.6 \\
right to privacy & 2.9 & 2.7 & 2.7 & 2.4 & 2.7 \\
freedom of lifestyle & 2.8 & 2.4 & 2.8 & 2.3 & 2.6 \\
freedom of religion & 3.3 & 2.9 & 3.3 & 2.7 & 3.1 \\
$\begin{array}{l}\text { Political rights culture } \\
\text { rejection of political oppression }\end{array}$ & 1.5 & 1.4 & 1.6 & 1.4 & 1.5 \\
political action & & & & & \\
political interest & 3.2 & 2.5 & 3.3 & 2.5 & 2.9 \\
Judicial rights culture & 1.6 & 1.8 & 1.5 & 1.8 & 1.7 \\
right of due process & 3.3 & 2.9 & 3.1 & 2.9 & 3.1 \\
Socioeconomic rights culture & & & & & \\
socioeconomic equality & 2.2 & 2.4 & 2.2 & 2.1 & 2.2 \\
$\begin{array}{l}\text { Environmental rights culture } \\
\text { environmental action }\end{array}$ & 4.1 & 3.9 & 4.1 & 4.0 & 4.0 \\
environmental appreciation & & & & & \\
environmental sacrifice & 3.5 & 3.4 & 3.5 & 3.5 & 3.5 \\
environmental concem & 4.1 & 3.9 & 4.1 & 3.9 & 4.0 \\
& 3.7 & 3.6 & 3.8 & 3.7 & 3.7 \\
\hline
\end{tabular}

On the basis of table 3 we first made a synchronic comparison between private school students in 1995 and public school students in 1996, followed by a 
comparison between private school students in 2000 and public school students in 2001. Next we made a diachronic comparison between private school students in 1995 and 2000, and then between public school students in 1996 and 2001. Again we used a difference score of 0.5 or more as our criterion of relevance. The last column gives the combined average scores for all year groups.

In the synchronic comparison for 1995 and 1996 only one human right meets the criterion of relevance, namely rejection of political oppression: private school students reject political oppression (3.2), whereas public school students do not reject, but accept it (2.5).

The comparison between 2000 and 2001 revealed that private and public school students differ in regard to five human rights: the latter clearly value freedom of speech (2.9), the press (2.3), privacy (2.3), and lifestyle (2.7) less than the former (resp. 3.7, 2.9, 2.8, 3.3), and they do not reject, but accept political oppression (2.5), whereas private school students reject it (3.2). It is noteworthy that today these blue rights, which have a manifestly white historical background and evolution, are endorsed more strongly by students at multicultural private schools than by those at predominantly white, Afrikaans-medium public schools. Naturally the apartheid and post-apartheid eras play a crucial role in this regard.

In the diachronic comparison between 1995 and 2000 there are no relevant differences. The same applies to the 1996/2001 comparison.

These data enable us to answer question $2 \mathrm{a}$ in the introduction to this article: in $1995 / 1996$ there was only one demonstrable difference B and then only partly relevant, partly irrelevant $B$ between private school and Afrikaans-medium public school students in regard to the aforementioned blue rights, namely rejection of political oppression. But this difference had widened over the past five years (1995/1996-2000/2001), especially regarding the freedom of speech, the press, privacy, lifestyle, and rejection of political oppression.

By contrast students from both types of schools obtained similar scores in the areas of judicial, socioeconomic and environmental rights. Here it should be noted that scores on the socioeconomic rights culture are uniformly positive. The same applies to the environmental rights culture. Scores on environmental concern are extremely high among students at both types of schools.

To answer question $2 \mathrm{~b}$ (how do students assess a human rights culture?) we turn to the last column in table 3 . Students are negatively ambivalent towards the civil rights culture (average: 2.6); they are negatively ambivalent towards the political rights culture as well (average: 2.6 ); towards the judicial rights culture 
they are clearly negative (2.2); towards the socioeconomic rights culture they are clearly positive (average 4.0 ); and they are equally positive towards the environmental rights culture (average: 4.0 ). Overall we can say that our students manifestly have greater affinity with the second and third generation human rights culture than with the blue rights culture.

One finding that is certainly cause for concern on any time scale if it were to persist is the negative scores, among students at both types of schools, in the area of a judicial rights culture (average: 2.3 ). In a country like South Africa, which by and large has an adequately functioning judicial system that keeps the population together and enables the various population groups to enforce the legally required recognition of their dignity and rights, 'faith' in this system is vitally important. The negative scores and the decline among the public school year groups between 1995 and 2001, as may be cautiously inferred from the data (from 2.4 to 2.1), indicate that there is no question of any such 'faith' (Pessers 1999; Dreyer, Pieterse, Van der Ven 2001).

Another finding that must certainly be a cause of concern on any time scale if it were to persist is the extremely negative score on freedom of religion $(1.5,1.4$, 1.6, 1.4, average: 1.5 ). To some extent it is explicable. In the first place, South Africa is a religious country and most people take religion for granted on a dayto-day basis, hence the students may have experienced freedom of religion as an irrelevant theme. Secondly, the items in which this human right was operationalised may well have been phrased a bit radically from the students' point of view, causing them to assign it a low score. One of these items read: "prayers at public schools should be forbidden". Another read: "the freedom of atheists to make fun of God and religion is a legally protected right". Although this last item admittedly lacks sensitivity for the concerns of religious people, in itself it is an adequate operationalisation of the right to religious freedom, which would apply equally to an item, not included in the questionnaire, which could have read: "making fun of the godlessness of atheists is a legally protected right".

The reason why the extremely negative score on freedom of religion is cause for concern is that, historically, this human right - whose codification marked the end of the feudal marriage between throne and altar and ushered in democracy provided the basis for the origin and development of all the other human rights (Bellah 1998). That this fact is not just historical but remains topical to this day is evident in the fundamental significance of the separation between church and state in the debate on political Islamic fundamentalism that is raging around the world. It is not merely freedom of religion that is at issue, moreover, but also freedom within religion, including Christian religion. 


\section{Salvation and Human Rights Culture}

Having determined students' belief in salvation and their affinity with a human rights culture separately, in this final section we correlate the two themes. The question mentioned in the introduction is whether, and to what extent, their belief in salvation effects their human rights culture, either positively or negatively. Or does it have no effect at all? And did this effect change over time? To this end we examine if and how the various year groups at private and public schools differ in this regard (question 3a). We also ask the question what other factors contribute to the students' human rights culture, i.e. other religious factors and non-religious factors (question $3 \mathrm{~b}$ ). Against this background we investigate the effect of the students' belief in salvation on their human rights culture, both non-controled (3.1) and controled for for population characteristics (3.2), as we shall explain. Then we ask the question whether the belief in salvation effect we found is a real effect or an illusion (3.3), after which we close this chapter with an overall conclusion.

\subsection{Effect of Belief in Salvation on Human Rights Culture: non-controlled}

To determine the effect of the students' belief in salvation on their human rights culture we conducted a large number of regression analyses: one for each of the 15 human rights in each of the four year groups $(1995,1996,2000$ and 2001) B hence 60 analyses altogether. Each regression analysis yields one or more predictions: it indicates which salvation code(s) has predictive value for students' attitudes towards a particular human right. Predictive value can be positive, negative or nonexistent (zero).

Prediction should not be confused with causation. Only if a prediction is formulated as a theoretically based hypothesis may it be regarded as at least indicative of causation - that is to say, as indicating that the relevant soteriological code has at least some effect on the students' human rights culture. ${ }^{7}$ In this article we based our hypothesis on Geertz' distinction between religion as a model of and as a model for reality, as mentioned in the introduction. This is reflected in the relation between the belief in salvation in Christianity as a model of reality, that is of how the world is structured, and the belief in salvation as a model for reality that inspires people and triggers transformative action in the sense of human rights. The hypothesis is that belief in salvation acts as a motivational factor in optimising a human rights culture.

First we simply examine the effects of the salvation codes on the human rights culture, without taking all other religious and non-religious factors into account, which in statistical terms means that we did not control for them (table 4). In the 
next step we shall control for these factors, which see as relevant population characteristics (table 5).

Table 4 contains the necessary information. The horizontal axis refers to the human rights culture among the various year groups that were studied: students at private schools (Anglican and Catholic) in 1995, at (Afrikaans-medium) public schools in 1996, at private schools in 2000 and at public schools in 2001.

The vertical axis shows the five salvation codes encountered in our empirical study: code 1, God's immanent transcendent salvation in the present; code 2, God's transcendent salvation in the primordial past; code 3, God's transcendent salvation in the eschatological future; code 4, God's salvation in the intrapersonal and interpersonal/local domain; and code 5, God's salvation in a global sense.

The figures in the cells indicate the number of times that the relevant salvation code had a positive or negative value in relation to human rights culture, hence affected it either positively or negatively.

\begin{tabular}{|c|c|c|c|c|c|c|c|c|c|c|}
\hline \multirow[t]{3}{*}{ TABLE 4: } & \multicolumn{9}{|c|}{$\begin{array}{l}\text { Effect of salvation codes on human rights, non-controlled } \\
\text { (numbers betas) }\end{array}$} & \\
\hline & \multicolumn{2}{|c|}{$\begin{array}{l}\text { private } \\
1995\end{array}$} & \multicolumn{2}{|c|}{$\begin{array}{l}\text { public } \\
1996\end{array}$} & \multicolumn{2}{|c|}{$\begin{array}{l}\text { private } \\
2000\end{array}$} & \multicolumn{2}{|c|}{$\begin{array}{l}\text { public } \\
2001\end{array}$} & \multicolumn{2}{|l|}{ total } \\
\hline & pos. & neg. & pos. & neg. & pos. & neg. & pos. & neg. & pos. & neg. \\
\hline 1. present & 1 & - & 1 & - & 1 & - & - & - & 3 & - \\
\hline 2. past & - & - & 2 & - & 1 & 1 & 2 & 2 & 5 & 3 \\
\hline 3. future & - & 1 & - & 1 & - & 4 & - & 1 & - & 7 \\
\hline 4. personal & - & - & 1 & - & 2 & - & - & - & 3 & - \\
\hline 5. global & 2 & - & - & 3 & - & - & 2 & - & 4 & 3 \\
\hline
\end{tabular}

Like we did before, we first make a synchronic comparison: we compare the scores of private school students in 1995 with those of public school students in 1996 , and then those of private school students in 2000 with those of public school students in 2001. Next we make a diachronic comparison between the scores of private school students in 1995 and 2000, and those of public school students in 1996 and 2001 . Our criterion of relevance in these comparisons is a difference of 2 or more.

The synchronic comparison between 1995 and 1996 yields two relevant differences. Among private school students God's transcendent salvation in the primordial past (code 2) plays no role at all, whereas among public school students it does (+2). Also, God's salvation in a global sense (code 5) has a 
positive effect among private school students $(+2)$ and a negative effect among private school students $(-3)$.

The synchronic comparison between 2000 and 2001 reveales three differences. God's transcendent salvation in the eschatological future (code 3) has a far more negative effect on human rights culture among private school students $(-4)$ than among those at public schools (-1). Secondly, God's salvation in the personal/local domain (code 4) had a positive impact among private school students $(+2)$, whereas among public school students it did not have any effect, either positive or negative (zero). Finally, God's salvation in a global sense (code 5) has no effect on human rights culture at all among private school students (zero), whereas among public school students it has a positive effect $(+2)$.

The diachronic comparison between 1995 and 2000 produces some interesting results: among private school students the negative influence of God's transcendent salvation in the eschatological future on human rights culture (code 3) increased markedly (from -1 to -4 ). God's salvation in the personal/local domain (code 4) had a more positive influence (from zero to +2 ), whereas God's salvation in the global sense (code 5) lost its positive influence from +2 to zero). In other words, the codes referring to what is remote in space (code 5) or time (code 3 ) clearly changed. The remote space code (code 5) lost its positive effect (from +2 to zero) and the remote time code (code 3 ) became more negative (from -1 to -4).

Differences in the diachronic comparison between 1996 and 2001 are less great. What merits attention is that public school students' positive attitude towards the significance of God's salvation in the primordial past for their human rights culture (code 2 ) has changed into an ambivalent effect (from $+2 / 0$ to $+2 /-2$ ). At the same time the significance of God's salvation in a global sense (code 5) has changed from a negative effect $(-3)$ into a positive one $(+2)$.

These results can be summarised in terms of our earlier distinction between two kinds of salvation codes: those relating to the character of God's salvific action (immanent transcendence in the present, transcendence in the past, and transcendence in the future), and those relating to the place of God's salvific action (personal/local and global). The last two columns of totals in table 4 show that students at both types of schools assign the character of God's salvation codes a slightly more positive effect on their human rights culture $(8$ times) than the place of God's action codes ( 7 times). On the other hand, the character of God's salvation codes are assigned a far greater negative effect on human rights (10 times) than the place of God's action codes (3 times). 


\subsection{Effect of Belief in Salvation on Human Rights Culture: controlled}

Thus far we have given the results of the 60 regression analyses that were conducted to determine the effects of students' belief in salvation on their human rights culture. Now we shall examine whether the effects that were found remain intact when we control for a number of relevant population characteristics among the students. To this end we conduct a further 60 regression analyses.

Why do we do that? It would not be the first time that we believe we have found effects of religious attitudes (e.g. our students' belief in salvation) on social attitudes (e.g. their human rights culture), only to discover that these are in fact pseudo-effects, because factors such as gender or political preference turn out to play a decisive role that 'explains away' the supposed influence of the religious attitudes. In other words, the inclusion of population characteristics may help to 'demythologise' pseudo-causal relations between salvation attitudes and human rights attitudes. We stress the point: inclusion of population characteristics may contribute to such demythologisation but it does not necessarily do so. In other words: the more relevant population characteristics one introduces into the regression analyses, the more robust the effect of the salvation codes may be considered $B$ that is, if any effect remains. This accords perfectly with empirical research methodology: to test a given hypothesis (here the effect of salvation attitudes on a human rights culture) one has to subject it to the most stringent conditions possible to see whether the hypothesis holds water and whether the effect remains intact. That is what we shall do next.

As in table 4, the horizontal axis in table 5 refers to the human rights culture among the year groups we studied. The vertical axis gives the five salvation codes that were studied empirically earlier. On the vertical axis we appended a number of relevant population characteristics to the salvation codes so as to control their relation to the human rights culture and determine whether there are any what we have called pseudo-effects. The population characteristics are divided into five groups: demographic, familial, political, cultural and religious. The demographic characteristics are: gender and age. The familial characteristic is home language. The political characteristics are: importance of politics, political preference, political communication with parents, and political agreement with significant others. The cultural characteristics are: ethnicity/transethnicity, and materialism/postmaterialism. The religious characteristics are: religious communication with parents, religious transfer by parents, religious steering by parents, Bible reading, religious saliency, church membership, church participation and rites of passage. 
TABLE 5: Effect of salvation codes on human rights culture, controlled for population characteristics (numbers betas)

\begin{tabular}{lllllllll} 
private & \multicolumn{3}{c}{ public } & \multicolumn{2}{c}{ private } & public & & total \\
1995 & 1996 & & 2000 & & 2001 & & & \\
pos. neg. & pos. & neg. & pos. & neg. & pos. & neg. & pos. & neg.
\end{tabular}

salvation codes

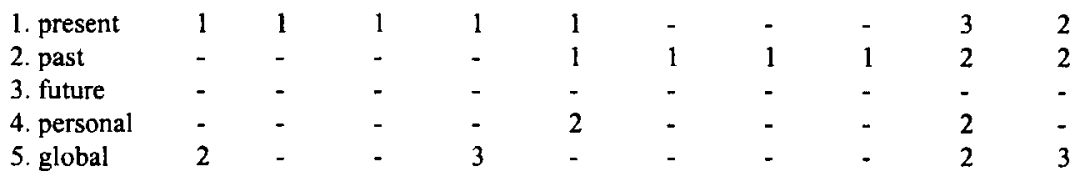

\begin{tabular}{|c|c|c|c|c|c|c|c|c|c|c|}
\hline \multicolumn{11}{|c|}{$\begin{array}{l}\text { population characteristics } \\
\text { demographic }\end{array}$} \\
\hline gender & 4 & - & 4 & 1 & - & 1 & 2 & 1 & 10 & 3 \\
\hline age & - & - & 2 & - & - & 2 & 1 & 1 & 3 & 3 \\
\hline \multicolumn{11}{|l|}{ familial } \\
\hline home language & (4) & $=$ & - & - & $(2)$ & - & (1) & - & (7) & - \\
\hline \multicolumn{11}{|l|}{ political } \\
\hline importance & 2 & - & 2 & 1 & 2 & 1 & 2 & - & 8 & 2 \\
\hline preference & - & - & (1) & - & (2) & - & - & - & (3) & - \\
\hline comm.parents & 1 & - & 2 & - & I & - & 2 & - & 6 & - \\
\hline agree others & - & - & 1 & - & - & - & - & 1 & 1 & 1 \\
\hline \multicolumn{11}{|l|}{ cultural } \\
\hline ethn./transethn. & (1) & - & - & - & (2) & - & (1) & - & (4) & - \\
\hline mat/postmat. & (1) & - & (3) & - & (1) & - & (2) & - & (7) & - \\
\hline \multicolumn{11}{|l|}{ religious } \\
\hline comm.parents & 2 & - & 1 & 1 & - & - & - & - & 3 & 1 \\
\hline transfer parents & - & 1 & - & 2 & - & 1 & - & 1 & - & 5 \\
\hline steering & - & - & - & - & 3 & - & - & 1 & 3 & 1 \\
\hline Bible reading & - & - & 1 & 3 & - & 1 & - & 5 & 1 & 9 \\
\hline $\begin{array}{l}\text { saliency } \\
\text { church }\end{array}$ & - & 1 & - & 1 & - & 2 & 1 & 2 & 1 & 6 \\
\hline$\overline{\text { membership }}$ & (1) & - & (1) & - & (1) & - & (1) & - & (4) & - \\
\hline church particip. & - & - & 1 & 1 & - & - & 2 & - & 3 & 1 \\
\hline rites of passage & - & - & 1 & - & 1 & - & - & - & 2 & - \\
\hline
\end{tabular}

Some of the population characteristics are underlined, because they were measured on a different scale from the other population characteristics and therefore require special statistical treatment and interpretation, with which we shall not weary our readers. These are: home language, political preference, ethnicity/transethnicity, materialism/postmaterialism, and church membership. ${ }^{8}$

Table 5 comprises two parts: the cells in the top part contain the effects of belief in salvation on human rights culture; those in the lower half contain the effects 
of the population characteristics on human rights culture. The aim, as mentioned already, is to determine if the effects of salvation attitudes on human rights culture established earlier (table 4), remain intact when controlled for the aforementioned population characteristics (table 5). Our criterion of relevance is again a difference of 2 or more.

\section{Effect of belief in salvation on human rights culture}

As in the case of the previous tables, we first make a synchronic comparison between private and public school students in 1995 and 1996 and again in 2000 and 2001, followed by a diachronic comparison between private school students in 1995 and 2000 and between public school students in 1996 and 2001.

In the synchronic comparison between the private school group of 1995 and the public school group of 1996 the only discernible differences are in respect of God's salvation in a global sense (code 5): whereas private school students assign it positive significance for their human rights culture $(+2)$, public school students assigned it negative significance $(-3)$. The comparison between the 2000 and 2001 groups reveal again just one difference, namely in regard to God's personal salvation (code 4): private school students assign it a positive value $(+2)$ whereas public school students assign it no value at all (zero).

The diachronic comparison between the 1995 and 2000 groups reveal two differences: in regard to God's personal salvation (code 4) the 2000 group endorses its significance for their human rights culture (+2), whereas the 1995 group did not (zero); in regard to God's global salvation (code 5) the position is reversed: the 1995 group assigned it positive significance $(+2)$ and the 2000 group no longer does (zero). Between the 1996 and 2001 groups only one difference remains: by 2001 the negative effect of the code 'God's global salvation' (code 5) in 1996 (-3) has disappeared altogether (zero).

The results can be summarised in terms of the distinction between the character of God's salvific action codes (immanent transcendence in the present, transcendence in the past, and transcendence in the future), and the place of God's salvific action codes (personal/local and global). The last two columns in table 5 show that students at the two types of schools assign a slightly greater positive effect ( 5 times) and a slightly greater negative effect (4 times) to character of God's salvation codes than to the place of God's salvation codes ( 4 and 3 times respectively).

\section{Effect of population characteristics on human rights culture}

But belief in salvation is not the only factor affecting human rights culture. The population characteristics appended to the salvation codes in table 5 also have a clear impact, as is evident in the last two columns of totals. Of the demographic 
characteristics B and indeed of all the population characteristics B gender has the greatest effect on human rights culture: in 10 out of 13 instances female students have a greater preference for a human rights culture than their male peers. However, the diachronic comparison shows that the importance of gender has declined appreciably in the intervening five years. Age appears to have an ambivalent effect $(+3,-3)$. With regard to the familial characteristic we investigated, home language is a major factor: in two thirds of the cases students who speak an official black language at home have a stronger preference for a human rights culture than those who speak English, Afrikaans or some other language. Among the political characteristics political importance and political communication with parents manifestly have the greatest explanatory power: in 8 of the 10 cases students who consider politics important support a human rights culture more strongly than those who find politics unimportant, while the students who regularly discuss politics with their parents all have a great affinity with a human rights culture than those who do not discuss it with their parents. Political preference (ANC) plays a lesser role than the other two political characteristics: it features in only 3 instances. Among cultural characteristics materialism/postmaterialism plays a major role: in over two thirds of the cases students with a moderate to strong postmaterialistic orientation show stronger support for a human rights culture than those with a materialistic approach. Among religious characteristics religious transfer by parents, Bible reading and religious saliency appear to have the greatest explanatory power, albeit a negative one: all of them have a wholly or almost wholly negative effect on the students' human rights culture. This does not apply, or any rate not without qualification, to church membership and church participation. In the case of church membership Anglican and Methodist students have a greater preference for a human rights culture than students belonging to the Catholic Church, the Afrikaans Reformed Churches or other Christian churches. As for church participation, in 3 of the 4 cases it appears that the more frequently students attend church services, the greater their preference for a human rights culture.

It is interesting to ask the question which is frequently raised in the literature, namely whether and to what extent human rights are a product of Western thought only, as they appear not to fit into the mind-set of non-Western populations, especially in developing countries. What we see in table 5 is as follows: to the extent that our students come from black families and speak their own languages at home there is a two thirds chance that they are more in favour of human rights than their peers who speak English, Afrikaans or some other language at home. This is the case irrespective of their ethnic or transethnic orientation and of their materialistic or postmaterialistic orientation. 


\subsection{Effect of Belief in Salvation on Human Rights Culture: Reality or Illusion?}

All this raises a question: to what extent have the effects of students' belief in salvation on their human rights culture remained intact after the inclusion of certain relevant population characteristics in the regression analyses? Did they in fact remain intact or did they turn out to be pseudo-effects? To answer this question, table 6 combines the non-controlled positive and negative effects (see total columns in table 4) with the controlled positive and negative effects (see total columns in table 5), so that we can compare them.

TABLE 6: Comparison of salvation effects: non-controlled and controlled (numbers betas)

\begin{tabular}{llllc} 
& \multicolumn{2}{c}{ non-controlled } & \multicolumn{2}{c}{ controlled } \\
& pos. & neg. & pos. & neg. \\
1. present & 3 & - & 3 & 2 \\
2. past & 5 & 3 & 2 & 2 \\
3. future & - & 7 & - & - \\
4. personal & 3 & - & 2 & - \\
5. global & 4 & 3 & 2 & 7 \\
Total & 15 & 13 & 9 & 7 \\
\hline
\end{tabular}

Table 6 shows that in the non-controlled analyses the effects of the salvation codes on human rights culture were positive in 15 instances and negative in 13 (together 28). In the controlled analyses positive effects are discernible in 9 instances and negative effects in 7 (together 16). In other words, in almost half of the cases ( 28 minus 16 ) the non-controlled effects prove to be pseudo-effects - quite a powerful demythologisation of the effects of the salvation codes!

If one examines the table in more detail, the code of God's salvation in the present appears to have retained its three positive effects, but with the addition of two negative ones. The codes of God's salvation in the primordial past appear to have dwindled in regard to both positive effects (from +5 to +2 ) and negative effects (from -3 to -2 ). The most drastic decline is in the case of God's salvation in the eschatological future. In the non-controlled analysis this code plays a clearly negative role (-7); in the controlled analysis it has no influence whatever: neither positive nor negative (zero). The only code that remains at all intact is that of God's personal salvation $(+3,+2)$. Finally, the positive effects of the code of God's global salvation have shrunk by half (from +4 to +2 ). 


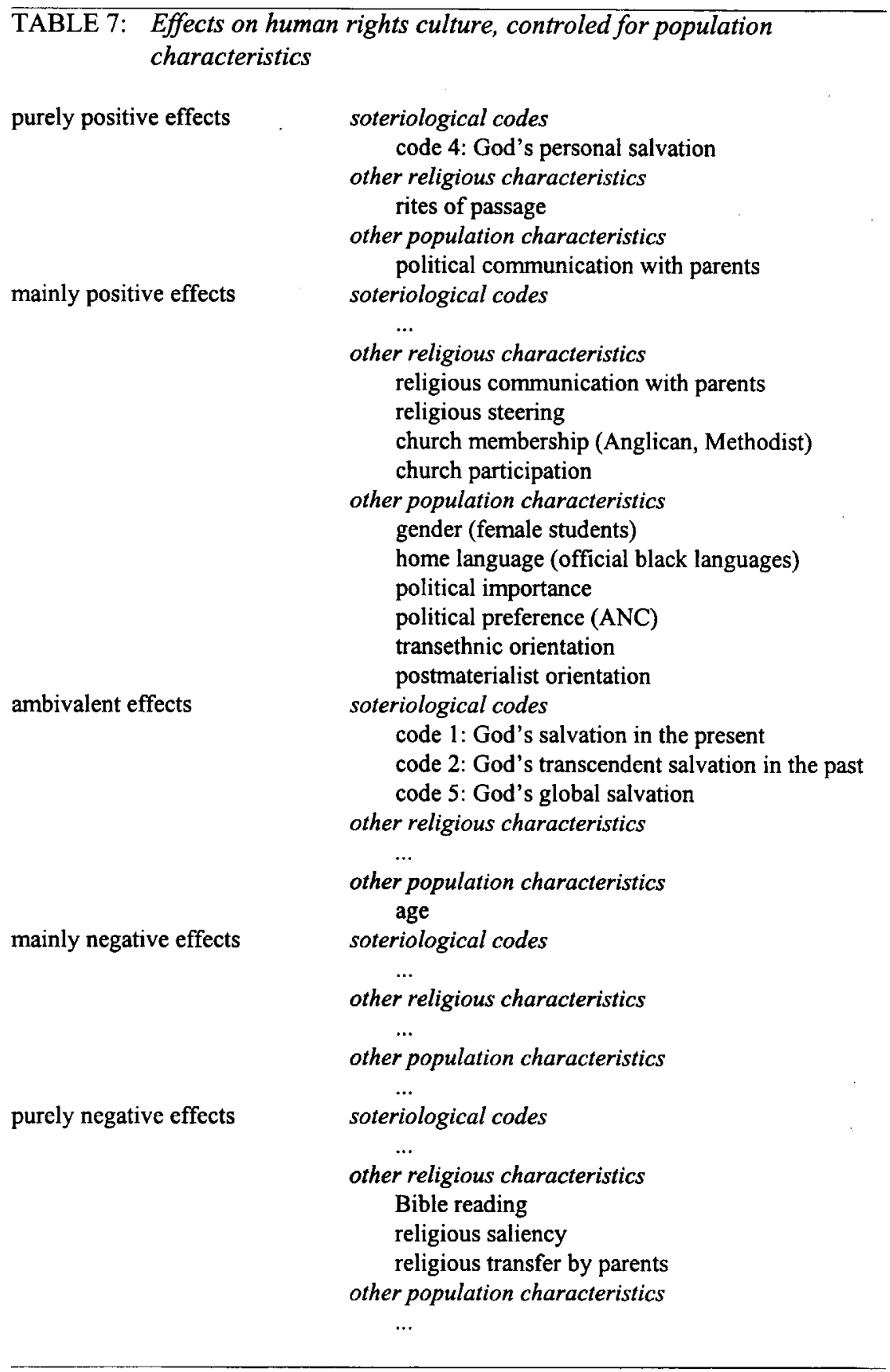


But the really crucial question is obviously: what is the meaning of the effects of the soteriological codes on a human rights culture once they have been controlled for the relevant population characteristics? From table 7 one infers the following general answer: the students' salvation codes have both a real but non-exclusive and a differentiated effect on their human rights culture. The salvation codes have a differentiated effect inasmuch as one code has a positive effect (code 4), other codes have an ambivalent effect (code 1, 2, 5), and yet another one (code 3) has no effect at all, either positive or negative - that is, zero effect. The effect is non-exclusive inasmuch as other religious characteristics also have an impact, sometimes a greater one, such as church membership, and because other, nonreligious population characteristics have as strong or even a stronger effect, for example gender. We highlight this by dividing the different kinds of effects into five groups in table 7: purely positive effects; mainly positive effects, in which the positive loading outweighs the negative; ambivalent effects, in which positive and negative loadings are (more or less) evenly balanced; mainly negative effects, in which negative loading outweighs positive; and lastly, purely negative effects. In addition the factors are divided into three groups: soteriological codes, other religious characteristics and other population characteristics.

From table 7 it is evident that there is one salvation code that definitely has a purely positive effect on the students' human rights culture, namely God's personal salvation (code 4).

In addition a few other factors have a purely or mainly positive effect on their human rights culture: the religious institutional factors, namely rites of passage, church membership (at least in the case of Anglicans and Methodists) and church participation. There are also two religious socialisation factors that positively affect human rights culture, namely religious communication with parents and religious steering.

Finally certain other population characteristics have a purely or mainly positive influence on human rights culture, namely political factors like political communication with parents, considering politics important and political preference (at least in the case of ANC preference). There is a demographic factor that has a mainly positive impact: gender (female students), as the familial factor we inserted in our research, namely home language, also has a mainly positive influence, at least in the case of students who speak one of the official black languages at home. Lastly, two cultural orientations have a mainly positive effect: a transethnic orientation and a postmaterialistic orientation. 
Some factors have an ambivalent effect on human rights culture, especially code 1: God's salvation in the present; code 2: God's salvation in the past; and code 5: God's global salvation. Age also plays a role.

Since no factors have a mainly negative effect, the remainder have a purely negative influence. These comprise exclusively religious characteristics: Bible reading, religious transfer by parents and religious saliency.

As mentioned already, the remaining salvation code, God's salvation in the eschatological future, is fully demythologised and plays no role at all.

To sum up: as stated already, we found that the students' belief in salvation had a very real effect on their human rights culture, albeit a non-exclusive, differentiated one. That is to say, their belief in God's personal salvation - the only code with a positive effect - is not the only factor influencing their human rights culture, since other religious characteristics as well as nonreligious population characteristics also have an impact, and sometimes a far greater one. In addition students' belief in salvation in respect of the other soteriological codes have either an ambivalent effect (God's salvation in the present, in the past and global salvation) or zero effect (God's salvation in the future).

\section{Evaluative Overall Conclusion}

In terms of the questions posed in the introduction, the overall picture emerging from these data is fairly easy to describe.

To the first question about belief in God's salvation our answer is that students of both types of schools, however much they may differ in respect of multicultural as opposed to monocultural character, wholeheartedly agree with the five empirical salvation codes. By and large the picture has not changed much over the past five years.

To the second question about a human rights culture our answer is that in regard to blue rights the difference between the two types of schools has grown greater over the past five years: private school students clearly subscribe more to these rights than those at Afrikaans-medium public schools. For the rest there are no significant differences between students at the two types of schools in regard to the judicial, economic and environmental human rights culture, also not over the past five years. As noted above, special concern is called for in the case of judicial rights and the right to religious freedom. 
As for the third question regarding the influence of belief in God's salvation on a human rights culture, our answer is as follows. Even though the students agree wholeheartedly with the proffered salvation codes, it does not mean that their belief in salvation has a predominantly positive effect on their human rights culture. The effect is differentiated and, moreover, not entirely exclusive. As we have seen, the soteriological code of God's personal salvation has a purely positive effect, whereas the other codes have either an ambivalent effect (God's salvation in the present and in the past and God's global salvation) or no overall effect at all (God's future salvation).

It is noteworthy that having a strong belief in salvation as such does not mean that this belief ipso facto has a strong positive effect on human rights culture. That are two different phenomena. A strong belief may have a strong positive impact, but it also may have a a weak impact, no impact or even a negative impact, just as a weak belief can have either a weak or a strong impact. As indicated, the strongest modes of belief in salvation appeared to be God's salvation in the eschatological future (code 3) and God's salvation in personal and community life (code 4), as we can see from table 2 . Whereas the last code appears to have a purely positive impact on the students' human rights culture, albeit not a strong impact, the first appeared to have no effect at all on their attitudes to human rights, at least when the impact of salvation codes is controlled for the population characteristics mentioned (table 6).

From all this we arrive at the following conclusion in regard to the salvation codes. If we want to promote a human rights culture among students on the basis of their belief in salvation, we would be wise to incorporate purely and mainly positive factors in our activity, more particularly the belief in God's personal salvation. We would also be wise to deal with the ambivalent factors in such a way that their negative tendency is not given a chance to develop. This applies particularly to belief in God's salvation in the present and in the past, and God's global salvation.

Does that mean that in the liturgy, sermons, religious education and pastoral counselling those codes that entail a longer time span (e.g. God's salvation in the past and in the future) and those that entail greater spatial dimensions (e.g. God's global salvation) should be relegated to the background so as to obviate their ambivalent impact on a human rights culture? By no means, at least not if one reflects more closely on the significance of the spatial and temporal dimensions. Expansion of the spatial dimension, implying that God's salvation is extended to comprehend humankind universally in a global sense, is both intrinsic to the human rights culture and the crux of the Christian conception of salvation. By the same token, expansion of the temporal dimension, implying that God's salvation is extended to comprehend the chain of generations, especi- 
ally future generations, is - once again - intrinsic to the moral basis of the human rights culture and an indispensable heritage of the Christian religion. The secret is to see the extension of horizons of space and time as an expansion of the here and now, not as its abrogation. For the meaning of God's salvific action, especially in its global, universal and future-oriented sense, can only be revealed and experienced here and now - not 'there' and 'then'. After all, 'there' is 'there' viewed from 'here', and 'then' is 'then' viewed from 'now'. The local touches the global, as the global permeates the local.

But that is not all. The manner in which such a broadening of horizons is incorporated into liturgy, sermons, religious education and pastoral counselling also calls for special attention. We have seen that important forms of religious praxis (e.g. Bible reading), the transfer of religious insights, and the conviction that faith in God, Jesus and their Spirit constitutes a major, if not a decisive, existential perspective (religious saliency) - all these have a predominantly negative effect on a human rights culture. The paradox is that the God of the Hebrew Bible and the New Testament is a God of human flourishing in freedom, justice and love; yet the religious practices we have just mentioned have neutralised and even counteracted this message, evidenced by their negative impact on human rights culture, which is surely to be seen as a translation - morally mandatory, adapted to present-day life and thought - of the same biblical message. Above all, it is important that this message should be presented and exemplified in freedom, and freedom implies not just freedom of engagement, but also freedom to question and doubt, maybe (temporarily) reject - even abandon the church and the faith altogether. Human freedom can be restricted, even stifled, by an excess of Bible reading, religious transfer and religious saliency! In a nutshell: religious freedom does not only imply freedom of religion, but also freedom in religion.

\section{NOTES}

1. This article derives from an extensive study which forms part of the project "Religion and human rights among South African youth" (RHR project). It is based on data from a questionnaire investigation among grade 11 students in private (Catholic and Anglican) and Afrikaans-medium public schools in the Pretoria-Johannesburg region in 1995/1996 and 2000/2001, which is scheduled to be repeated in 2005 . Because of the security situation and for political and methodological reasons, educationists explicitly advised us against including schools in Soweto and the townships in the research population. For the sake of the statistical comparison of these year groups, moreover, we were obliged to removed the scores of certain groups of students - which we collected and reported on in earlier publications - from our comprehensive data set. Firstly, this chapter is confined to those students who call themselves Christian, in both the data sets of 1995/1996 and $200 / 2001$. This is because students who turned out to be of a different religious persuasion or claimed to be non-religious refrained, on our instructions, from answering questions pertaining to the theme of salvation. Secondly, in regard to the public schools data for 1996, we restrict ourselves to schools from which we were able to collect data in 2001 as well. This is because there 


\section{JOURNAL OF EMPIRICAL THEOLOGY 16(2003)2, 50-86}

appears to have been a change of policy in some public schools regarding the relations between church and state in the five year interval between 1996 and 2001. Whereas we were able to include several Afrikaans-medium public schools in 1996, some of these schools refused us access in 2001 because of altered perceptions in this sphere on the part of the ministry of education in Gauteng province, where the Johannesburg/Pretoria district is located. For the sake of the statistical comparison of the 1996 and 2001 data, we unfortunately had to scrap the scores of students from some Afrikaans-medium public schools from the 1996 data set.

2. This is the only way of escaping theological dualism which has always and everywhere determined religious and theological thought, as Schoonenberg $(1955 ; 1969 ; 1986)$ argues in all his works.

3. Past actions occurred in what was then the present, and the actions that will - we anticipate, for we have no knowledge of future actions! - take place in the future will be enacted in what will then be the present.

4. This semiotic structure results from a free application of the soteriological instrument developed earlier by R. Jeurissen 1993 in his study of the religious inspiration of the peace movement. It was adapted by interpreting the topic of peace, which is focal in Jeurissen's study, in terms of the topic of salvation in our study.

5. We interpret these average scores as follows: 1.00-1.79: total disagreement, 1.80-2.59: disagreement, 2.60-3.39: ambivalence (2.60-2.99: negative ambivalence; 3.00-3.39: positive ambivalence); 3.40-4.19: agreement, 4.20-5.0: full agreement.

6. For the civil and judicial rights culture we used items from the measuring instrument by McClosky and Zaller (1984, table 7.8); for the political rights culture we used items from the Core Questionnaire 'Democratisation in Eastern Europe' by the Erasmus Foundation for Democracy and from the Nijmegen Programme, 'Sociaal-Culturele Ontwikkelingen in Nederland' (SOCON) by Felling, Peters \& Scheepers (1992); for the socioeconomic rights culture we used items from the International Social Survey Programme (ISSP); and for the environmental rights culture we used items from the British social attitudes source book (Brook et al., 1992; S2) and the SOCON survey. 7. For the asymmetry between prediction and causation, see P. Ricoeur, Main trends in philosophy, New York/London: Holmes \& Meier 1979, 64. It is possible to 'leap' from one to the other: "We need not be too unhappy about making the intellectual leap to a causal interpretation" (H.M. Blalock, Social Statistics (revised 2nd edition), McGraw-Hill, Tokyo 1979, 469).

8. Here we deal with so-called polynomial variables, which are inserted into the regression analyses as 'dummy variables', in that one of these polynomial variables functions as reference category, in relation to which the loading of the other polynomial variables is computed. The polynomial variables are then combined into 'compound variables' in order to compute their total standardised beta effect, so that this beta effect can be compared with the beta effects of the other variables; cf. R. Eisinga, P. Scheepers \& L. van Snippenburg, The standardized effect of a compound of dummy variables or polynomial terms, in: Quality and Quantity 25(1001) 103-114.

\section{LITERATURE}

Andresen, J. (ed.) (2001). Religion in Mind. Cognitive Perspectives on Religious Belief, Ritual, and Experience. Cambridge: The University of Cambridge Press.

Barth, K. (1960). Die kirchliche Dogmatik 1/2. Zürich: EVZ-Verlag.

Barth, K. (1964). Die kirchliche Dogmatik 1/1. Zürich: EVZ-Verlag.

Bellah, R.N. (1998).Is there a common American culture? In: Journal of the American Academy of Religion 66, 3, 613-626.

Berkhof, H. (1973). Christelijk geloof. Nijkerk: Callenbach.

Brook, L. et al. (1992). British social attitudes. Harts.

Coetzee, P.H. \& Roux, A.P.J. (eds.) (1998). Philosophy from Africa. Halfway House: International Thomson Publishing. 


\section{HUMAN RIGHTS: A CHANNEL FOR SALVATION?}

Dreyer, J.S., Pieterse, H.J.C. \& Van der Ven, J.A. (2001). Religious and human rights attitudes among South African youth in a time of transformation. In: F.A. Swanepoel (ed.), Religion, morality and transformation. Pretoria: Unisa.

Felling, A., Peters, J. \& Scheepers, P (1992). Individual Changes in the Netherlands. Amsterdam: Steinmetz archives.

Fresen, P. A. (1995). Self-knowledge in the writings of Catherine of Siena. Pretoria: Diss. Unisa.

Geertz, C. (1969). Religion as a Cultural System. In: The World Yearbook of Religion. The Religious Situation, I: 639-688.

Haas, M. (1994). Improving human rights. London.

Halkes, C.J.M. (1989). ...en alles zal worden herschapen. Gedachten over de heelwording van de schepping in het spanningsveld tussen natuur en cultuur. Baarn: Ten Have.

Heidegger, M. (1979). Sein und Zeit. Tübingen: Niemeyer. $15^{\text {th }}$ edition.

Jeurissen, R. (1993). Peace and Religion. Diss. KU Nijmegen. Kampen/Weinheim: Kok/ Deutsche Studienverlag.

Khumalo, C. (1999). Worship of the "almighty gun". Challenge No 54, 16-17.

König, A. 1999. Kom Jesus kort na 2000? Cape Town: Lux verbi.

Makhudu, N. (1993). Cultivating a climate of co-operation through ubuntu. In: Enterprise 68, 40-41.

McClosky, H. \& Zaller, J. (1984) The American ethos, Cambridge, Mass.

McGrath, A.E. (1994). Christian Theology. An Introduction. Oxford: Blackwell.

Metz, J.B. (1981). Jenseits bürgerlicher Religion. München/Mainz.

Moltmann, J. (1964). Theologie van de hoop. Utrecht: Ambo.

Ndlovu, W. (1999). Christian youth to work with police. Challenge No 55, 18.

Pessers, D. (1999). Liefde, solidariteit en recht. Een interdisciplinair onderzoek naar het wederkerigheidsbeginsel. Amsterdam: University of Amsterdam Press.

Pieterse, H.J.C. (1993). Praktiese teologie as kommunikatiewe handelingsteorie. Pretoria: HSRC Publishers.

Pieterse, H.J.C. (2001). Sermon preparation in context. In: Practical Theology in South Africa, 16, 2, 97-118.

Pieterse, H.J.C. (2001a). Preaching in a context of poverty. Pretoria: Unisa Press.

Prinsloo, E.D. (1998). Ubuntu culture and participatory management. In: P.H. Coetzee \& A.P.J. Roux (eds.). Philosophy from Africa. Halfway House: International Thomson Publishing.

Ricoeur, P. (1984). Time and narrative I-III. Chicago: Chicago University Press.

Ricoeur, P. (1994). Oneself as another. Chicago: The Univesity of Chicago Press.

Ricoeur, P. (1998). Thinking Biblically. Exegetical and hermeneutical studies. Chicago: The University of Chicago Press.

Schillebeeckx, E. (1977). Christus und die Christen. Freiburg: Herder.

Schonnenberg, P. (1955). Het geloof van ons doopsel. Deel I. Den Bosch: Malmberg

Schoonenberg, P. (1969). Hij is een God van mensen. Den Bosch.

Schoonenberg, P. (1986). Auf Gott hin denken. Freiburg.

Van der Ven, J.A. (1998). Formation of the moral self. Grand Rapids, Mi/Cambridge, U.K.: William B. Eerdmans.

Van der Ven, J.A., Dreyer, J.S. \& Pieterse, H.J.C. (2001). Human rights in the name of God? In: Religion and Theology 8, 1-2, 165-206. 
Van der Ven, J.A., Dreyer J.S., \& Pieterse H.J.C. (2000a). Attitudes towards human rights among South African youth. In: Religion and Theology 7, 2, 111-141.

Van der Ven, J.A., Dreyer J.S., \& Pieterse H.J.C. (2000b). Social location of attitudes towards human rights among South African youth. In: Religion and Theology 7, 3, 249-283.

Van Ruler, A.A. (1969). Theologisch werk, Deel I. Nijkerk: Callenbach.

Hendrik J.C. Pieterse is Professor of Practical Theology at the University of Pretoria (South Africa). Johannes A. van der Ven is professor of Pastoral and, more specifically, Empirical Theology at the University of Nijmegen, the Netherlands. Address for correspondence: Prof. Dr. J.A. van der Ven, University of Nijmegen, Faculty of Theology, Erasmusplein 1, NL-6525 HT Nijmegen. 